\title{
A selective removal of the secondary hydroxy group from ortho-dithioacetal-substituted diarylmethanols
}

\author{
Anna Czarnecka ${ }^{1}$, Emilia Kowalska ${ }^{1}$, Agnieszka Bodzioch ${ }^{1}$, Joanna Skalik ${ }^{1}$, \\ Marek Koprowski ${ }^{1}$, Krzysztof Owsianik ${ }^{1}$ and Piotr Bałczewski ${ }^{* 1,2}$
}

\author{
Full Research Paper \\ Address: \\ ${ }^{1}$ Group of Synthesis of Functional Materials, Centre of Molecular and \\ Macromolecular Studies, Polish Academy of Sciences, Sienkiewicza \\ 112, 90-363 Łódź, Poland, and 2Department of Structural and \\ Material Research, Institute of Chemistry, Environmental Protection \\ and Biotechnology, Faculty of Mathematics and Natural Sciences, Jan \\ Długosz University in Częstochowa, Armii Krajowej 13/15, 42-200 \\ Częstochowa, Poland \\ Email: \\ Piotr Bałczewski - pbalczew@cbmm.lodz.pl \\ * Corresponding author \\ Keywords: \\ diarylmethanes; diarylmethanols; 1,3-dithiane; selective reduction; \\ sodium cyanoborohydride; zinc iodide
}

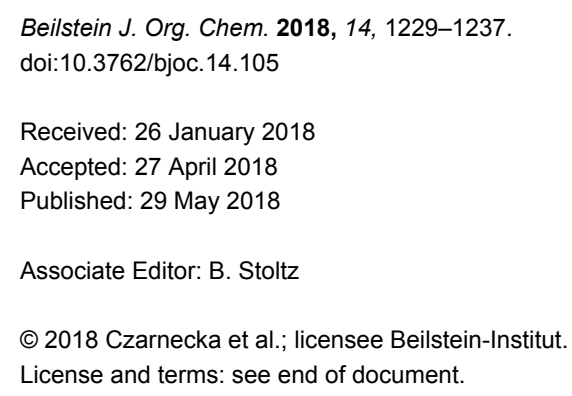

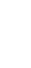




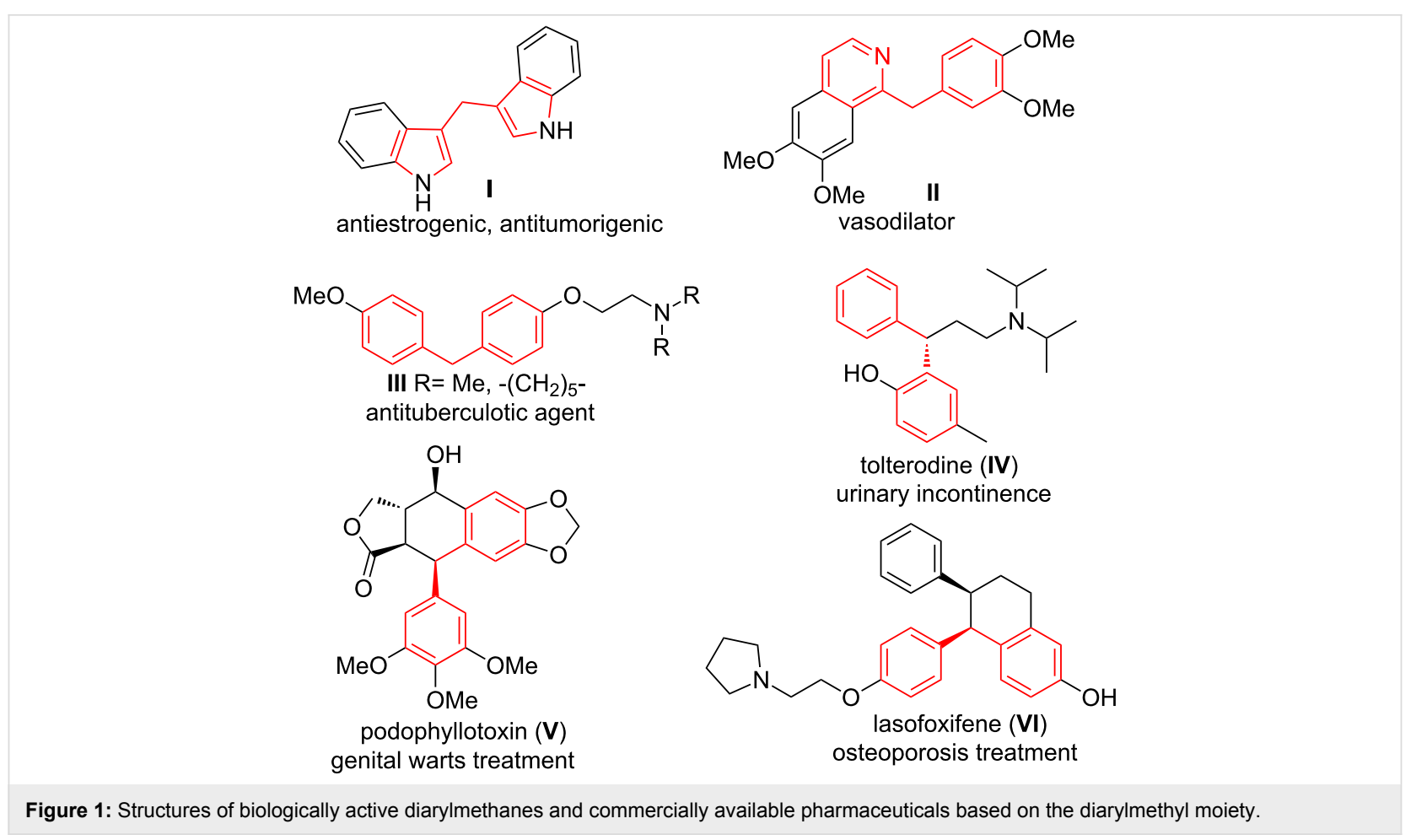

(Figure 1). The diarylmethyl motif also plays a pivotal role in supramolecular architectures of calixarenes [13] and orthocyclophanes [14].

A special, ortho-carbonyl-substituted diarylmethyl scaffold is present in the key substrates for aromatic cyclodehydration, also known as the Bradsher reaction [15], which leads to fused, polycyclic aromatic hydrocarbons [16-19]. This type of reaction found applications in synthesis of organic, optoelectronic materials [20-22].

Metal-catalyzed cross-coupling reactions (e.g., Suzuki-Miyaura, Stille, Kumada, Hiyama or Negishi couplings) play a key role in the preparation of diarylmethanes. However, the reactions involving sulfur-containing moieties have not been reported yet (Scheme 1) [1]. It is noteworthy that under certain conditions, the Pd-catalyzed cross-coupling reactions of substrates containing an 1,3-dithiane moiety are feasible, like in the case of the 2-arylation of 2-aryl-substituted 1,3-dithianes. However, in the case of 2-benzyl-substituted 1,3-dithianes, a tandem elimination/1,3-dithiane ring opening followed by a Pd-catalyzed $\mathrm{C}-\mathrm{S}$ bond formation was observed instead [23].

Diarylmethanes were also obtained in the Friedel-Crafts reactions of arenes with primary benzyl alcohols, aryl acetals, and benzyl esters [1]. Benzyl fluorides (in 1,1,1,3,3,3-hexafluoroisopropanol in the presence of a catalytic amount of trifluoroacetic acid [24]) as well as benzotrifluorides (employed in hydrodefluorinative Friedel-Crafts alkylations catalyzed by alumenium ions [25]) were interesting, alternative substrates for alcohols, acetals and esters.

A large group of synthetic procedures for the synthesis of diarylmethanes are deoxygenations of secondary diarylmethyl alcohols with hydride sources. These reactions require a preliminary $\mathrm{C}-\mathrm{OH}$ bond activation by Brønsted or Lewis acids. Several reagent systems have recently been employed to achieve this goal, including: $\mathrm{NaBH}_{4}-\mathrm{CF}_{3} \mathrm{COOH}$ [26], $\mathrm{ZnI}_{2}-\mathrm{NaBH}_{3} \mathrm{CN}$ [27], HI-P red [28], $\mathrm{H}_{3} \mathrm{PO}_{2}-\mathrm{I}_{2}$ [29,30], $\mathrm{Mo}(\mathrm{CO})_{6}$-Lawesson's reagent [31], $\mathrm{PBr}_{3}$ [32], $\mathrm{BF}_{3} \cdot \mathrm{Et}_{2} \mathrm{O}-\mathrm{di}$ butyl ether [33] and silanes $(\mathrm{Si}-\mathrm{H})$ in the presence of various Lewis acids: $\mathrm{B}\left(\mathrm{C}_{6} \mathrm{~F}_{5}\right)_{3}$ [34-36], $\mathrm{InCl}_{3}$ [37,38], $\mathrm{H}_{3}\left[\mathrm{PW}_{12} \mathrm{O}_{40}\right] \times n \mathrm{H}_{2} \mathrm{O}$ [39], $\mathrm{Ca}\left(\mathrm{NTf}_{2}\right)_{2}$ [40], $\mathrm{Bi}(\mathrm{OTf})_{3}$ [41], $\mathrm{Sn}(\mathrm{IV})$-montmorillonite [42] and $\mathrm{PdCl}_{2}$ [43]. It is interesting that Seto et al. reported that $\mathrm{Et}_{3} \mathrm{SiH}-\mathrm{CF}_{3} \mathrm{COOH}, \mathrm{TMSCl} / \mathrm{NaI}$ failed to reduce secondary $\mathrm{OH}$ groups in diheteroaromatic systems and the reduction with $\mathrm{H}_{2} / \mathrm{Pd} / \mathrm{C}-\mathrm{ZnBr}_{2}$ was very slow [32]. On the other hand, some rigid diarylmethanols were successfully reduced to benzo $[b]$ indeno[2,1- $d]$ thiophenes using the $\mathrm{Et}_{3} \mathrm{SiH}-\mathrm{CF}_{3} \mathrm{COOH}$ system which was reported in the patent literature [44].

Benzophenones were also reduced to diarylmethanes using supercritical iPrOH at $350{ }^{\circ} \mathrm{C}[1], \mathrm{BF}_{3} \cdot \mathrm{OEt}_{2} / \mathrm{H}_{2} \mathrm{O}$ [33] and $\mathrm{PhSiH}_{3} / \mathrm{MoCl}_{2} \mathrm{O}_{2}\left(\mathrm{H}_{2} \mathrm{O}\right)_{2}$ [45]. 
The reductive deoxygenation reactions of diarylmethanols proceed via carbocationic species, which are formed by protonation or complexation of alcohols by Brønsted or Lewis acids. Therefore, diarylmethanols bearing electron-donating substituents $(\mathrm{EDG}=$ methyl, methoxy) are reduced much faster than diarylmethanols with electron-withdrawing groups $\left(\mathrm{EWG}=\mathrm{CF}_{3}, \mathrm{C}(\mathrm{O}) \mathrm{OR}\right)$ on (hetero)aryl moieties. Consequently, dramatically decreased yields have been observed in these cases $[32,33]$. It has also been reported that ortho-substituents on aryl moieties give lower yields in the reduction processes [33]. Moreover, the $\mathrm{OH}$ reduction under acidic conditions cannot be carried out in the presence of other sensitive functional groups. For instance, ether cleavage and dehalogenation (I but not $\mathrm{Cl}$ and $\mathrm{Br}$ ) are common, side reactions due to either the high acidity which is necessary to generate carbocationic species or due to the use of strongly reducing reaction conditions [28-30,46-52]. In this context, a serious challenge is still the selective and direct removal of the $\mathrm{OH}$ group from alcohols $\mathrm{Ar}_{2} \mathrm{CH}(\mathrm{OH})$ without excessive, side reactions. Especially in the presence of other functionalities such as, for instance, when a reductively sensitive ortho-1,3-dithianyl group is attached to one of the aryl moieties, side products are to be expected. This task is additionally difficult to accomplish due to a chemical similarity of oxygen and sulfur, two neighboring heteroatoms from the main group VI of the periodic table. A longer atomic radius of sulfur than oxygen should make the $\mathrm{C}-\mathrm{S}$ bond weaker and more reactive than the $\mathrm{C}-\mathrm{O}$ bond and consequently the reduction of the former should a priori occur preferentially [53-55].

According to the best of our knowledge, there are no literature reports concerning selective reductions of dibenzylic hydroxy groups in the presence of ortho-acetal or ortho-thioacetal functions. Such reductions may give an access to new series of ortho-formyl-protected diarylmethanes as well as their formylmodified derivatives, obtained after deprotection of the 1,3dithianyl group with one of the available methods [56].

Herein, we present the first example of a selective and efficient reduction of ortho-1,3-dithianylaryl(aryl)methanols leading to ortho-1,3-dithianylaryl(aryl)methanes using the $\mathrm{ZnI}_{2}$ $\mathrm{Na}(\mathrm{CN}) \mathrm{BH}_{3}$ reductive system (Scheme 1). The use of zinc iodide is critical in this system. It was used for the first time in dichloroethane by Lau et al. to reduce aryl ketones, aldehydes, benzylic, allylic and tertiary alcohols, including the first example of a diarylmethanol (benzhydrol) reduction to diarylmethane (diphenylmethane) [27].

\section{Results and Discussion}

The synthesis of ortho-1,3-dithianylaryl(aryl)methanols 5 and $\mathbf{6}$, as key substrates for the $\mathrm{OH}$ reduction, has been realized ac- cording to the procedure shown in Scheme 2 including: 1) protection of the formyl group in ortho-bromoaldehydes 1 and 2 with 1,3-propanedithiol, 2) the $\mathrm{Br} / \mathrm{Li}$ exchange reaction in the resulting ortho-bromo-1,3-dithianes 3 and 4 with $n$-BuLi followed by condensation with a second (hetero)aromatic aldehyde $\mathrm{Ar}^{2}-\mathrm{CHO}$.

The reduction of ortho-1,3-dithianylaryl(aryl)methanols 5 and $\mathbf{6}$ to ortho-1,3-dithianylaryl(aryl)methanes 7 and 8 has been carried out using Lau's procedure with $\mathrm{ZnI}_{2}$ (1.5 equiv) and $\mathrm{Na}(\mathrm{CN}) \mathrm{BH}_{3}$ (7 equiv) in dichloroethane (DCE) and a solventmodified protocol employing the same reagents in benzene. In literature, only few applications of the $\mathrm{ZnI}_{2}-\mathrm{Na}(\mathrm{CN}) \mathrm{BH}_{3}$ system in DCE have been described for reduction of diarylmethanols that do not contain acid-sensitive, formyl protecting, acetal or thioacetal groups $[20,27,57-60]$ and for the reduction of aromatic aldehydes and ketones [28]. The bromo function in such diarylmethanols [60], as well as $\mathrm{Cl}, \mathrm{Br}, \mathrm{C}(\mathrm{O}) \mathrm{OMe}, \mathrm{MeO}$, MeS and $\mathrm{NO}_{2}$ groups in aromatic aldehydes and ketones, being reduced to methyl and methylene groups, respectively [27], are tolerated by this reagent system.

The use of other procedures for deoxygenation of alcohols $\mathbf{5 d}$, 6a and $6 \mathbf{b}$ with metal hydride donors, such as $\mathrm{NaBH}_{4}$ and $\mathrm{LiAlH}_{4}$ in various combinations with $\mathrm{ZnI}_{2}$ and $\mathrm{AlCl}_{3}$ failed [61-63]. For instance, the reaction with $\mathrm{NaBH}_{4}$ itself and $\mathrm{NaBH}_{4} / \mathrm{ZnI}_{2} / \mathrm{THF}$ at room temperature and reflux only recovered the substrates. The same result was obtained at room temperature with $\mathrm{NaBH}_{4} / \mathrm{AlCl}_{3} / \mathrm{THF}$, while at reflux the whole substrate was consumed and three unidentified products were formed lacking the SCHS and $\mathrm{ArCH}_{2} \mathrm{Ar}$ characteristic signals in ${ }^{1} \mathrm{H}$ NMR spectra. With $\mathrm{NaBH}_{4} / \mathrm{CF}_{3} \mathrm{COOH} / \mathrm{rt}$, the substrate underwent decomposition.

In our case, the use of the Lau's procedure in DCE for the reductive deoxygenation of ortho-1,3-dithianyl-substituted alcohols 5a-h containing unsubstituted $\mathrm{Ar}^{1}$ phenyl ring and electron-donating $\mathrm{Ar}^{2}$ groups, gave diarylmethanes $\mathbf{7 a}-\mathbf{h}$ in $26-95 \%$ yields (Table 1, entries 1-9).

Surprisingly, the reduction of the $\mathrm{Ar}^{1}$ piperonyl series $\mathbf{6 a}, \mathbf{b}$ failed under the same reaction conditions and only the substrates could be isolated. In this case, a replacement of DCE by benzene resulted in a successful formation of the desired diarylmethanes 8a,b in 95\% yield (Table 1, entries 10-12). In addition, diarylmethanols $\mathbf{5 b}$ and $\mathbf{6 b}$ with the bulky group $\mathrm{Ar}^{2}=3,4,5$-trimethoxyphenyl required refluxing in the relevant solvent (benzene or DCE) to complete the reduction (Table 1, entries 3 and 12). At room temperature, only $40 \%$ of the substrates underwent conversion to diarylmethanes $\mathbf{7 b}$ and $\mathbf{8 b}$ due to their low solubility at this temperature. Attempts to synthe- 


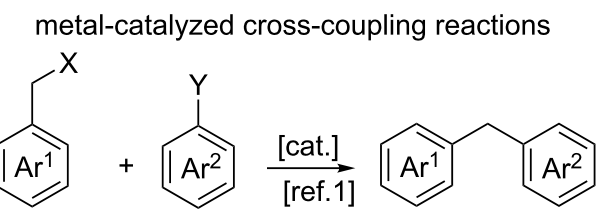

I. $\mathrm{X}=\mathrm{Cl}, \mathrm{Br}, \mathrm{OP}(\mathrm{O})(\mathrm{OEt})_{2} ; \mathrm{Y}=\mathrm{B}(\mathrm{OH})_{2}, \mathrm{SnBu}_{3}, \mathrm{MgBr}, \mathrm{Si}(\mathrm{OR})_{3}, \mathrm{BR}_{2}$;

[cat.] = $\mathrm{Pd}(\mathrm{II}), \mathrm{Ni}(\mathrm{II}), \mathrm{Cu}(\mathrm{I})$

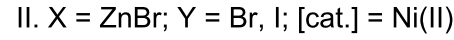

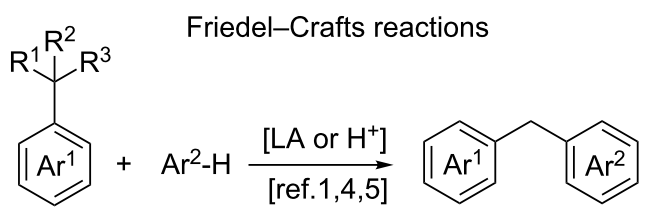

I. $\mathrm{R}^{1}, \mathrm{R}^{2}=\mathrm{H}, \mathrm{R}^{3}=\mathrm{OH} ;[\mathrm{LA}]=\mathrm{TiCl}_{4}$

II. $\mathrm{R}^{1}, \mathrm{R}^{2}=-\mathrm{O}\left(\mathrm{CH}_{2}\right)_{3} \mathrm{O}-, \mathrm{R}^{3}=\mathrm{H} ;\left[\mathrm{H}^{+}\right]=$TFA, TFSA

III. $R^{1}, R^{2}=H, R^{3}=F ;\left[H^{+}\right]=$TFA, HFIP

IV. $R^{1}, R^{2}, R^{3}=F ;[L A]=\left\{[R u] i B u_{2} A l H\right\}^{+}[X]^{-}$

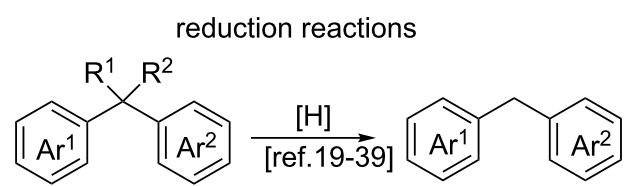

I. $\mathrm{R}^{1}=\mathrm{H}, \mathrm{R}^{2}=\mathrm{OH}, \mathrm{OAc} ;[\mathrm{H}]=\mathrm{NaBH}_{4}-\mathrm{TFA}, \mathrm{ZnI}_{2}-\mathrm{NaBH}_{3} \mathrm{CN}, \mathrm{HI}-\mathrm{P}_{\text {red }}$, $\mathrm{H}_{3} \mathrm{PO}_{2}-\mathrm{I}_{2}, \mathrm{Mo}(\mathrm{CO})_{6}, \mathrm{PBr}_{3}, \mathrm{BF}_{3}-\mathrm{Et}_{2} \mathrm{O} /$ dibutyl ether, silanes in

the presence of: $\mathrm{B}\left(\mathrm{C}_{6} \mathrm{~F}_{5}\right)_{3}, \mathrm{InCl}_{3}, \mathrm{H}_{3}\left[\mathrm{PW}_{12} \mathrm{O}_{40}\right]_{n} \mathrm{H}_{2} \mathrm{O}, \mathrm{Ca}\left(\mathrm{NTf}_{2}\right)_{2}, \mathrm{Bi}(\mathrm{OTf})_{3}$,

$\mathrm{Sn}$ (IV)-montmorillonite, $\mathrm{PdCl}_{2}, \mathrm{Et}_{3} \mathrm{SiH}$-TFA

II. $\mathrm{R}^{1}, \mathrm{R}^{2}=\mathrm{O} ;[\mathrm{H}]=\mathrm{iPrOH}, \mathrm{BF}_{3}-\mathrm{Et}_{2} \mathrm{O} / \mathrm{H}_{2} \mathrm{O}, \mathrm{PhSiH}_{3} /[\mathrm{Mo}]$

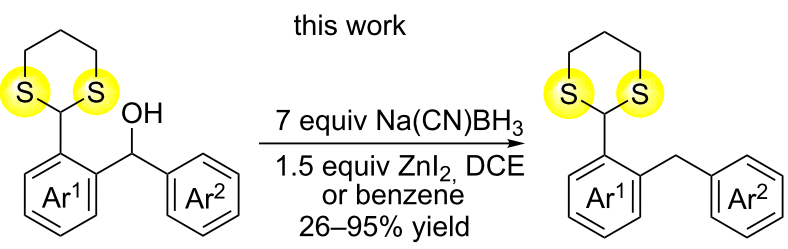

Scheme 1: Various synthetic approaches to diarylmethanols (literature review and this work).

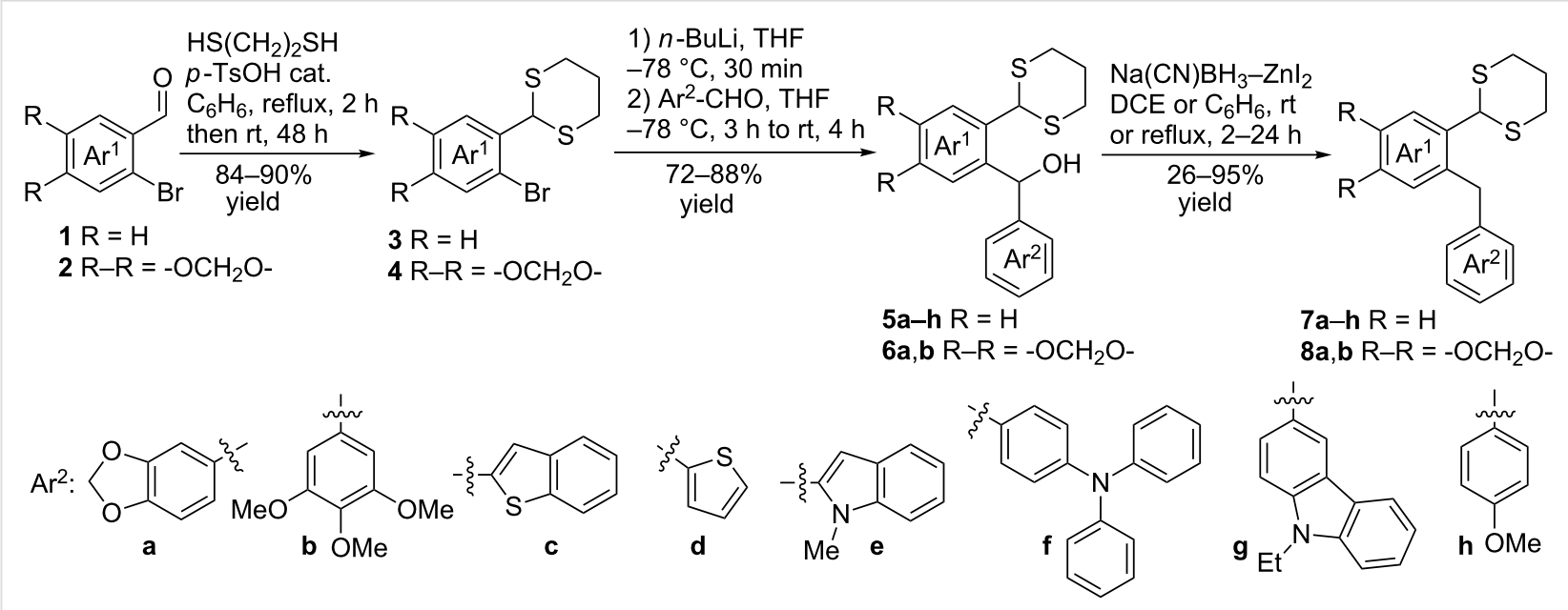

Scheme 2: A general strategy for the synthesis of ortho-1,3-dithianylaryl(aryl)methanols $\mathbf{5}$ and $\mathbf{6}$, and their reduction to the corresponding ortho-1,3dithianylaryl(aryl)methanes. 
Table 1: A selective reduction of ortho-1,3-dithianylaryl(aryl)methanols to ortho-1,3-dithianylaryl(aryl)methanes using the $\mathrm{Znl} 2 / \mathrm{Na}(\mathrm{CN}) \mathrm{BH} \mathrm{H}_{3}$ reducing system.<smiles>OC(c1ccc2c(c1)OCO2)c1ccccc1C1SCCCS1</smiles>

DCE

$5 a$

2<smiles>COc1cc(C(O)c2ccccc2C2SCCCS2)cc(OC)c1OC</smiles>

$5 b$<smiles>OC(c1cc2ccccc2s1)c1ccccc1C1SCCCS1</smiles>

5c<smiles>OC(c1cccs1)c1ccccc1C1SCCCS1</smiles>

$5 d$<smiles>Cn1c(C(O)c2ccccc2C2SCCCS2)cc2ccccc21</smiles>

$5 e$

$$
\begin{aligned}
& \text { DCE } \\
& \text { DCE }
\end{aligned}
$$

DCE

72

DCE

DCE

DCE<smiles>OC(c1ccc(N(c2ccccc2)c2ccccc2)cc1)c1ccccc1C1SCCCS1</smiles>

$5 f$

24 $r t$<smiles>c1ccc(C2SCCCS2)c(Cc2ccc3c(c2)OCO3)c1</smiles>

$7 a$

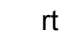

reflux<smiles>COc1cc(Cc2ccccc2C2SCCCS2)cc(OC)c1OC</smiles>

$95^{a}$

85

$7 b$<smiles>c1ccc(C2SCCCS2)c(Cc2cc3ccccc3s2)c1</smiles>

$7 c$<smiles>c1csc(Cc2ccccc2C2SCCCS2)c1</smiles>

7d<smiles>Cn1c(Cc2ccccc2C2SCCCS2)cc2ccccc21</smiles>

$7 e$<smiles>c1ccc(N(c2ccccc2)c2ccc(Cc3ccccc3C3SCCCS3)cc2)cc1</smiles>

$7 f$
70

95

26

95 
Table 1: A selective reduction of ortho-1,3-dithianylaryl(aryl)methanols to ortho-1,3-dithianylaryl(aryl)methanes using the $\mathrm{Znl}_{2} / \mathrm{Na}(\mathrm{CN}) \mathrm{BH}_{3}$ reducing system. (continued)

8<smiles>CCn1c2ccccc2c2cc(C(O)c3ccccc3C3SCCCS3)ccc21</smiles>

$5 g$<smiles>COc1ccc(C(O)c2ccccc2C2SCCCS2)cc1</smiles>

$5 \mathrm{~h}$

10<smiles>OC(c1ccc2c(c1)OCO2)c1cc2c(cc1C1SCCCS1)OCO2</smiles>

$6 a$

11<smiles>COc1cc(C(O)c2cc3c(cc2C2SCCCS2)OCO3)cc(OC)c1OC</smiles>

6b
DCE

3

DCE

$\mathrm{C}_{6} \mathrm{H}_{6}$

$\mathrm{C}_{6} \mathrm{H}_{6}$

$\mathrm{C}_{6} \mathrm{H}_{6}$

24

72

reflux<smiles>CCn1c2ccccc2c2cc(Cc3ccccc3C3SCCCS3)ccc21</smiles>

$7 g$<smiles>COc1ccc(Cc2ccccc2C2SCCCS2)cc1</smiles>

$7 \mathrm{~h}$<smiles>c1cc2c(cc1Cc1cc3c(cc1C1SCCCS1)OCO3)OCO2</smiles>

$8 a$<smiles>COc1cc(Cc2cc3c(cc2C2SCCCS2)OCO3)cc(OC)c1OC</smiles>

$8 b$

aYield calculated based on the consumed substrate.

size diarylmethanols 6 with electron-withdrawing groups $\left(\mathrm{Ar}^{2}=p-\mathrm{NO}_{2}, p-\mathrm{CF}_{3}\right)$ were also unsuccessful. They proved to be unstable: the reaction of lithiated 4 with $p$-nitro and $p$-trifluoromethylbenzaldehyde gave five products in the crude reaction mixture and even more complex mixtures of products after silica gel column chromatography. We also tried to remove the $\mathrm{OH}$ group using the Pd-catalytic hydrogenolysis (Scheme 3).

In case of $\mathbf{6 b}(X=S)$, no reaction occurred and only the substrate was recovered, most probably due to poisoning of the catalyst by the 1,3-dithianyl sulfur atoms. However, the successful catalytic hydrogenolysis $(5 \% \mathrm{Pd} / \mathrm{C})$ of diphenylmethanol to diphenylmethane, described in literature [64], encouraged us to try the Pd-catalyzed reduction of the oxygen

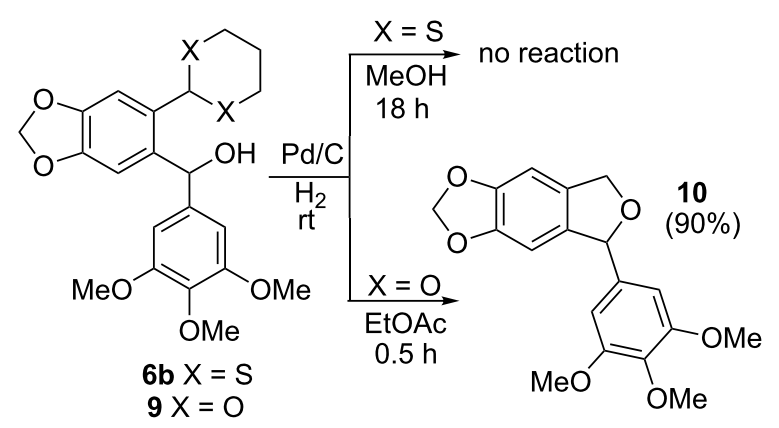

Scheme 3: Attempts of the $\mathrm{OH}$ removal in ortho-1,3-dithianyl- $6 \mathrm{~b}$ and ortho-1,3-dioxanylaryl(aryl)methanols 9 using the Pd-catalyzed hydrogenolysis reaction. 
analog $9(\mathrm{X}=\mathrm{O})$ as a representative of the ortho-1,3-dioxanyl series. In this case, instead of the expected ortho-1,3-dioxanyl diarylmethane analog of $\mathbf{8 b}, 1,3$-dihydroisobenzofuran $\mathbf{1 0}$ was obtained in $90 \%$ yield, within $30 \mathrm{~min}$, as a result of preferential deacetalization over the dibenzylic $\mathrm{OH}$ deoxygenation. This is followed by cyclization and final deoxygenation of the secondary monobenzylic $\mathrm{OH}$ group in the resulting lactol. This product is known in literature and was obtained by hydrogenolysis or pyrolysis of the corresponding ortho-1,3-dioxolanyl [65] and ortho-hydroxymethyl [66] substituted diarylmethanols, respectively. It is worth mentioning that the reduction of 9 with $\mathrm{ZnI}_{2}-\mathrm{Na}(\mathrm{CN}) \mathrm{BH}_{3}$ caused decomposition of the starting material. The described reduction process involving 1,3-dithianyl derivatives is facilitated by oxophilic zinc which preferentially binds to the $\mathrm{OH}$ oxygen atoms (bond dissociation energies for $\mathrm{Zn}-\mathrm{O}$ and $\mathrm{Zn}-\mathrm{S}$ are 284 and $205 \mathrm{~kJ} / \mathrm{mol}$, respectively) [67]. The weakened $\mathrm{C}-\mathrm{O}$ bond is thus more susceptible to the borohydride attack to produce the corresponding diarylmethanes. Most probably, electrondonating groups on aryls facilitate both $\mathrm{Zn}$ complexation and stabilization of the intermediate carbocationic species formed.

\section{Conclusion}

In summary, a new example of the selective functional group transformation of diarylmethanols $\left(\mathrm{Ar}^{1} \mathrm{Ar}^{2} \mathrm{CH}(\mathrm{OH})\right)$ to diarylmethanes $\left(\mathrm{Ar}^{1} \mathrm{Ar}^{2} \mathrm{CH}_{2}\right)$ has been performed. It is important for the sulfur-containing substrates for which metal-catalyzed cross-coupling reactions fail. The dibenzylic $\mathrm{OH}$ group has been preferentially reduced with the $\mathrm{ZnI}_{2} / \mathrm{Na}(\mathrm{CN}) \mathrm{BH}_{3}$ system in the presence of an ortho-dithioacetal moiety to give ortho1,3-dithianylaryl(aryl)methanes in 26-95\% yields under mild reaction conditions. Thus, the ortho-1,3-dithianyl moiety joins other functionalities tolerated by this reagent system [47]. Since analogous 1,3-dioxanyl derivatives, in our hands, decomposed or led to other products during the attempted catalytic hydrogenolysis, the elaborated protocol is the only one up to date that enables synthesis of ortho-formyl-protected diarylmethane derivatives under reductive conditions. The latter may be used as key substrates both for the synthesis of biologically active diarylmethanes or for the synthesis of (hetero)acenes via the Bradsher protocol.

\section{Supporting Information}

\section{Supporting Information File 1}

General experimental information, characterization data and copies of ${ }^{1} \mathrm{H},{ }^{13} \mathrm{C}$ NMR spectra.

[https://www.beilstein-journals.org/bjoc/content/ supplementary/1860-5397-14-105-S1.pdf]

\section{Acknowledgements}

The scientific work was financed from the Science Resources (National Science Centre-Poland) 2014-2017 as research grant UMO-2013/11/B/ST5/01610.

\section{References}

1. Mondal, S.; Panda, G. RSC Adv. 2014, 4, 28317-28358. doi:10.1039/C4RA01341G

2. Sun, H. H.; Paul, V. J.; Fencial, W. Phytochemistry 1983, 22, 743-745. doi:10.1016/S0031-9422(00)86974-5

3. Chen, I.; McDougal, A.; Wang, F.; Safe, S. Carcinogenesis 1998, 19, 1631-1639. doi:10.1093/carcin/19.9.1631

4. McDougal, A.; Gupta, M. S.; Ramamoorthy, K.; Sun, G.; Safe, S. H. Cancer Lett. 2000, 151, 169-179. doi:10.1016/S0304-3835(99)00406-1

5. Abdelrahim, M.; Newman, K.; Vanderlaag, K.; Samudio, I.; Safe, S. Carcinogenesis 2006, 27, 717-728. doi:10.1093/carcin/bgi270

6. Li, H.; Zhu, X.; Yao, G.; Wang, Z. J. Surg. Res. 2015, 195, 271-276. doi:10.1016/j.jss.2015.01.016

7. Wai, J. S.; Egbertson, M. S.; Payne, L. S.; Fisher, T. E.; Embrey, M. W.; Tran, L. O.; Melamed, J. Y.; Langford, H. M.; Guare, J. P.; Zhuang, L.; Grey, V. E.; Vacca, J. P.; Holloway, M. K.; Naylor-Olsen, A. M.; Hazuda, D. J.; Felock, P. J.; Wolfe, A. L.; Stillmock, K. A.; Schleif, W. A.; Gabryelski, L. J.; Young, S. D. J. Med. Chem. 2000, 43, 4923-4926. doi:10.1021/jm000176b

8. Panda, G.; Parai, M. K.; Das, S. K.; Shagufta; Sinha, M.; Chaturvedi, V.; Srivastava, A. K.; Manju, Y. S.; Gaikwad, A. N.; Sinha, S. Eur. J. Med. Chem. 2007, 42, 410-419. doi:10.1016/j.ejmech.2006.09.020

9. Upadhayaya, R. S.; Vandavasi, J. K.; Vasireddy, N. R.; Sharma, V.; Dixit, S. S.; Chattopadhyaya, J. Bioorg. Med. Chem. 2009, 17, 2830-2841. doi:10.1016/j.bmc.2009.02.026

10. Kerrebroeck, P. V.; Kreder, K.; Jonas, U.; Zinner, N.; Wein, A. Urology 2001, 57, 414-421. doi:10.1016/S0090-4295(00)01113-4

11. Canel, C.; Moraes, R. M.; Dayan, F. E.; Ferreira, D. Phytochemistry 2000, 54, 115-120. doi:10.1016/S0031-9422(00)00094-7

12. Gennari, L.; Merlotti, D.; Martini, G.; Nuti, R. Expert Opin. Invest. Drugs 2006, 15, 1091-1103. doi:10.1517/13543784.15.9.1091

13. Conn, M. M.; Rebek, J., Jr. Chem. Rev. 1997, 97, 1647-1668. doi:10.1021/cr9603800

14. Lee, W. Y.; Park, C. H.; Kim, H.-J.; Kim, S. J. Org. Chem. 1994, 59, 878-884. doi:10.1021/jo00083a033

15. Bradsher, C. K. J. Am. Chem. Soc. 1940, 62, 486-488. doi:10.1021/ja01860a006

16. Bradsher, C. K. Chem. Rev. 1987, 87, 1277-1297. doi:10.1021/cr00082a001

17. Bodzioch, A.; Kowalska, E.; Skalik, J.; Bałczewski, P. Chem. Heterocycl. Compd. 2017, 53, 11-20. doi:10.1007/s10593-017-2015-y

18. Bodzioch, A.; Marciniak, B.; Różycka-Sokołowska, E.; Jeszka, J. K.; Uznański, P.; Kania, S.; Kuliński, J.; Bałczewski, P. Synfacts 2012, 8, 619. doi:10.1055/s-0031-1291065

19. Bałczewski, P.; Kowalska, E.; Skalik, J. 10-Thiosubstituted pentahydroxyanthracene derivatives, a method of their preparation and intermediate compounds. Eur. Pat. Appl. EP 2886539 A1 20150624, June 24, 2015.

20. Park, J.-I.; Chung, J. W.; Kim, J.-Y.; Lee, J.; Jung, J. Y.; Koo, B.; Lee, B.-L.; Lee, S. W.; Jin, Y. W.; Lee, S. Y. J. Am. Chem. Soc. 2015, 137, 12175-12178. doi:10.1021/jacs.5b01108 
21. Bodzioch, A.; Marciniak, B.; Różycka-Sokołowska, E.; Jeszka, J. K.; Uznański, P.; Kania, S.; Kuliński, J.; Bałczewski, P. Chem. - Eur. J. 2012, 18, 4866-4877. doi:10.1002/chem.201101909

22. Bałczewski, P.; Skalik, J.; Uznański, P.; Guziejewski, D.; Ciesielski, W. RSC Adv. 2015, 5, 24700-24704. doi:10.1039/C4RA14071K

23. Dockrey, S. A. B.; Makepeace, A. K.; Schmink, J. R. Org. Lett. 2014, 16, 4730-4733. doi:10.1021/ol502428h

24. Hemelaere, R.; Champagne, P. A.; Desroches, J.; Paquin, J.-F. J. Fluorine Chem. 2016, 190, 1-6. doi:10.1016/j.jluchem.2016.08.003

25. Forster, F.; Metsänen, T. T.; Irran, E.; Hrobárik, P.; Oestreich, M. J. Am. Chem. Soc. 2017, 139, 16334-16342. doi:10.1021/jacs.7b09444

26. Gribble, G. W.; Leese, R. M.; Evans, B. E. Synthesis 1977, 172-176. doi:10.1055/s-1977-24308

27. Lau, C. K.; Dufresne, C.; Belanger, P. C.; Pietre, S.; Scheigetz, J. J. Org. Chem. 1986, 51, 3038-3043. doi:10.1021/jo00365a034

28. Dobmeier, M.; Herrmann, J. M.; Lenoir, D.; König, B. Beilstein J. Org. Chem. 2012, 8, 330-336. doi:10.3762/bjoc.8.36

29. Gordon, P. E.; Fry, A. J. Tetrahedron Lett. 2001, 42, 831-833. doi:10.1016/S0040-4039(00)02159-6

30. Gordon, P. E.; Fry, A. J.; Hicks, L. D. ARKIVOC 2005, No. 6, 393-400. doi:10.3998/ark.5550190.0006.634

31. Wu, X.; Mahalingam, A. K.; Alterman, M. Tetrahedron Lett. 2005, 46, 1501-1504. doi:10.1016/j.tetlet.2005.01.012

32. Nishigaya, Y.; Umei, K.; Watanabe, D.; Kohno, Y.; Seto, S. Tetrahedron 2016, 72, 1566-1572. doi:10.1016/j.tet.2016.02.005

33. Li, J.; Liu, Q.; Shen, H.; Huang, R.; Zhang, X.; Xiong, Y.; Chen, C. RSC Adv. 2015, 5, 85291-85295. doi:10.1039/C5RA14775A

34. Gevorgyan, V.; Liu, J.-X.; Rubin, M.; Benson, S.; Yamamoto, Y. Tetrahedron Lett. 1999, 40, 8919-8922. doi:10.1016/S0040-4039(99)01757-8

35. Gevorgyan, V.; Rubin, M.; Benson, S.; Liu, J.-X.; Yamamoto, Y. J. Org. Chem. 2000, 65, 6179-6186. doi:10.1021/jo000726d

36. Denancé, M.; Guyot, M.; Samadi, M. Steroids 2006, 71, 599-602. doi:10.1016/j.steroids.2006.03.002

37. Miyai, T.; Ueba, M.; Baba, A. Synlett 1999, 182-184. doi:10.1055/s-1999-2588

38. Baba, A.; Yasuda, M.; Nishimoto, Y.; Saito, T.; Onishi, Y. Pure Appl. Chem. 2008, 80, 845-854. doi:10.1351/pac200880050845

39. Egi, M.; Kawai, T.; Umemura, M.; Akai, S. J. Org. Chem. 2012, 77, 7092-7097. doi:10.1021/j0300889p

40. Meyer, V. J.; Niggemann, M. Chem. - Eur. J. 2012, 18, 4687-4691. doi:10.1002/chem.201103691

41. Narayana Kumar, G. G. K. S.; Laali, K. K. Org. Biomol. Chem. 2012, 10, 7347-7355. doi:10.1039/c2ob26046h

42. Tandiary, M. A.; Masui, Y.; Onaka, M. Tetrahedron Lett. 2014, 55, 4160-4162. doi:10.1016/j.tetlet.2014.05.042

43. Mirza-Aghayan, M.; Boukherroub, R.; Rahimifard, M. Tetrahedron Lett. 2009, 50, 5930-5932. doi:10.1016/j.tetlet.2009.08.043

44. Bell, M. G.; Muehl, B. S.; Winter, M. A. Dihydrobenzo(B)indeno(2,1-D)thiophene compounds, intermediates, processes, compositions, and methods. Eur. Pat. EP 832891, April 1, 1998.

45. Sousa, S. C. A.; Fernandes, T. A.; Fernandes, A. C. Eur. J. Org. Chem. 2016, 3109-3112. doi:10.1002/ejoc.201600441

46. Barton, D. H. R.; Jacob, M. Tetrahedron Lett. 1998, 39, 1331-1334. doi:10.1016/S0040-4039(98)00005-7

47. Shi, Y.; Dayoub, W.; Chen, G.-R.; Lemaire, M. Tetrahedron Lett. 2011, 52, 1281-1283. doi:10.1016/j.tetlet.2011.01.038
48. Mirza-Aghayan, M.; Boukherroub, R.; Rahimifard, M.; Zadmard, R. J. Iran. Chem. Soc. 2011, 8, 570-573. doi:10.1007/BF03249092

49. Purushothama Chary, K.; Santosh Laxmi, Y. R.; lyengar, D. S. Synth. Commun. 1999, 29, 1257-1261. doi:10.1080/00397919908086100

50. Kotsuki, H.; Ushio, Y.; Yoshimura, N.; Ochi, M. J. Org. Chem. 1987, 52, 2594-2596. doi:10.1021/jo00388a049

51. Fleming, B.; Bolker, H. I. Can. J. Chem. 1974, 52, 888-893. doi:10.1139/v74-143

52. Ishihara, K.; Hanaki, N.; Yamomoto, H. Synlett 1993, 127-129. doi:10.1055/s-1993-22373

53. Luh, T.-Y.; Ni, Z.-J. Synthesis 1990, 89-103. doi:10.1055/s-1990-26798

54. Rentner, J.; Kljajic, M.; Offner, L.; Breinbauer, R. Tetrahedron 2014, 70, 8983-9027. doi:10.1016/j.tet.2014.06.104

55. Saito, K.; Kondo, K.; Akiyama, T. Org. Lett. 2015, 17, 3366-3369. doi:10.1021/acs.orglett.5b01651

56. Burghardt, T. E. J. Sulfur Chem. 2005, 26, 411-427. doi:10.1080/17415990500195198

57. Alesso, E. N.; Bianchi, D. E.; Finkielsztein, L. M.; Lantaño, B.; Moltrasio, G. Y.; Aguirre, J. M. Tetrahedron Lett. 1995, 36, 3299-3302. doi:10.1016/0040-4039(95)00525-H

58. Wex, B.; Kaafarani, B. R.; Neckers, D. C. J. Org. Chem. 2004, 69 , 2197-2199. doi:10.1021/jo035769j

59. Wex, B.; Kaafarani, B. R.; Kirschbaum, K.; Neckers, D. C. J. Org. Chem. 2005, 70, 4502-4505. doi:10.1021/jo048010w

60. Tylleman, B.; Vande Velde, C. M. L.; Balandier, J.-Y.; Stas, S.; Sergeyev, S.; Geerts, Y. H. Org. Lett. 2011, 13, 5208-5211. doi:10.1021/ol202089t

61. Pan, X.; Wang, K.; Yu, W.; Zhang, R.; Xu, L.; Liu, F. Chem. Lett. 2015, 44, 1170-1172. doi:10.1246/cl.150390

62. Bhattacharyya, S.; Chatterjee, A.; Williamson, J. S. Synth. Commun. 1997, 27, 4265-4274. doi:10.1080/00397919708005050

63. Ley, S. V.; Tackett, M. N.; Maddess, M. L.; Anderson, J. C.; Brennan, P. E.; Cappi, M. W.; Heer, J. P.; Helgen, C.; Kori, M.; Kouklovsky, C.; Marsden, S. P.; Norman, J.; Osborn, D. P.; Palomero, M. Á.; Pavey, J. B. J.; Pinel, C.; Robinson, L. A.; Schnaubelt, J.; Scott, J. S.; Spilling, C. D.; Watanabe, H.; Wesson, K. E.; Willis, M. C. Chem. - Eur. J. 2009, 15, 2874-2914. doi:10.1002/chem.200801656

64. Marques, C. A.; Selva, M.; Tundo, P. J. Org. Chem. 1995, 60, 2430-2435. doi:10.1021/jo00113a024

65. Arnold, B. J.; Mellows, S. M.; Sammes, P. G. J. Chem. Soc., Perkin Trans. 1 1973, 1266-1270. doi:10.1039/p19730001266

66. Galletti, G. C.; Ward, R. S.; Pelter, A.; Goubet, D. J. Anal. Appl. Pyrolysis 1992, 24, 139-146. doi:10.1016/0165-2370(92)85025-G

67. Dean, J. A. Lange's Handbook of Chemistry, 15th ed.; Section 4; McGraw-Hill: New York, Montreal, 1998; 4.52. 


\section{License and Terms}

This is an Open Access article under the terms of the Creative Commons Attribution License

(http://creativecommons.org/licenses/by/4.0), which permits unrestricted use, distribution, and reproduction in any medium, provided the original work is properly cited.

The license is subject to the Beilstein Journal of Organic Chemistry terms and conditions:

(https://www.beilstein-journals.org/bjoc)

The definitive version of this article is the electronic one which can be found at:

doi:10.3762/bjoc.14.105 